\title{
KINETIC STUDY OF CONGO-RED PHOTO-CATALYTIC DEGRADATION IN AQUEOUS MEDIA USING ZINC OXIDE AS PHOTO CATALYST UNDER LED LIGHT
}

\author{
Shinwar A. Idrees ${ }^{\mathrm{a},}{ }^{*}$, Raad N. Salih ${ }^{\mathrm{a}}$, Khalat Bashir ${ }^{\mathrm{b}}$, Aram A. Hamasaeed ${ }^{\mathrm{b}}$ \\ ${ }^{a}$ Dept. of Chemistry, Faculty of Science, University of Zakho, Kurdistan Region, Iraq - (shinwar.idrees@uoz.edu.krd) \\ ${ }^{a}$ Dept. of Chemistry, Faculty of Science, University of Zakho, Kurdistan Region, Iraq - (raad.salih@uoz.edu.krd) \\ ${ }^{\mathrm{b}}$ Faculty of Science, University of Zakho, Kurdistan Region, Iraq - (khalatbashir@gmail.com) \\ ${ }^{\mathrm{b}}$ Faculty of Science, University of Zakho, Kurdistan Region, Iraq - (aramadnan70@gmail.com)
}

\begin{abstract}
:
The kinetic of photo catalytic degradation of Congo red dye using semiconductor in aqueous solution of $\mathrm{ZnO}$ has been studied. All photochemical experiments have been carried out in quartz photo cell $25 \mathrm{ml}$ capacity and the solvent used for all experiment was distilled water (D. W). The influence of temperature has been investigated as well. Spectrophotometric method was utilized for this work. Degradation kinetic has been done for absorption peak of Congo red at $497 \mathrm{~nm}$ and $344 \mathrm{~nm}$. Different method was applied for this purpose, and the results show that the degradation of Congo red was first order at $497 \mathrm{~nm}$ and zero order at $344 \mathrm{~nm}$. The degradation of CR dye were increased by increasing temperature from $20^{\circ} \mathrm{C}$ to $40^{\circ} \mathrm{C}$ and then degreased at $50{ }^{\circ} \mathrm{C}$ and this is due to desorption that occur at the semiconductor surface while; in case of $10^{\circ} \mathrm{C}$ the rate constant was higher than $20^{\circ} \mathrm{C}$. However, when changing the concentration the rate constant dose not changed regularly, this perhaps due to the fact that it does not follow the same order throughout the degradation process, and it does not obey Arrhenius law of activation energy.
\end{abstract}

KEYWORDS: Photo-catalytic degradation, kinetic of degradation, congo-red, activation energy

\section{INTRODUCTION}

Congo Red is the sodium salt of benzidinediazo-bis-1naphthylamine-4-sulfonic acid; a diazo dye that is red in alkaline solution and blue in acid solution and used especially as an indicator and as a biological stain.

Congo Red is an indicator dye that is blue-violet at $\mathrm{pH} 3.0$ and red at $\mathrm{pH}$ 5.0. It contains a 3,3'-(biphenyl-4,4'diyldidiazene-2,1-diyl)bis(4-aminonaphthalene-1-

sulfonate). It derives from a 3,3'-(biphenyl-4,4'-diyldidiazene-2,1-diyl)bis(4-aminonaphthalene-1-sulfonic

acid)[1]. Local water and water supplies are not pure in the sense they are deficient of most dissolved chemical compounds such as distilled or de ionized water, but they are polluted with a huge range of trace contaminant (element \& compound)[2-4]. Water is a universal solvent used by chemist's, due to it is dissolvability of most material comes with it, from solid, liquid \& gas state, so as rain falls through the atmosphere, rain water flow over the surface and through the earth; according to this mechanism it dissolve material during it is passed from the clouds, in addition; chemicals used by agricultural or industrial purposes [5].

Chemist's play an important role in discovering new method to solve environmental problems what is needed is an effective method for treating a toxic material. Irradiated semiconductors like $\left(\mathrm{TiO}_{2}, \mathrm{ZnO}, \mathrm{CdS}\right.$...etc.) effectively degrade all functional group for toxic compound, this process are called advanced oxidation processes (AOP's)[6]. AOP's generally involves generation of a non-selective and transient oxidizing species like hydroxyl radicals ( $\mathrm{HO}),\left(\mathrm{HO}_{2}{ }^{-}\right),\left(\mathrm{O}_{2}{ }^{-}\right)$ the most powerful oxidizing species is hydroxyl radical (HO) because hydroxyl radical shows the highest thermodynamic oxidation potential which is may be why hydroxyl radical based oxidation process have gained attention of many advanced oxidation processes technology development [7].

Most of the functional group of organic molecules is transparent in electromagnetic spectrum named by ultraviolet (UV.)- Visible (vis.) region at a wave length between 190-800 nm, However; sometimes we can obtain a useful data information from this regions of the spectrum [8] ultraviolet (UV.)- Visible (vis.) absorption molecular spectroscopy measurement are widely used for qualitative and quantitative applications of organic and inorganic ions and molecules,[9] hence; UV.-vis. Spectroscopy is a powerful method for quantitative analysis which is used in chemical research, mathematically; beer's law are used for the determination of intensity ratio according to the relation $(\mathrm{A}=\mathrm{abc})$ where (A) is absorbance (a) is molar extinction coefficient, (b) is a path length and (c) is concentration [9]analysis by spectrophotometric kinetic method are differ from the equilibrium or stoichiometric methods, methods of kinetic are made under dynamic conditions in which the change in concentration of both reactant and product depend on the time [10].

Advanced oxidation process (AOPs) including Photo degradation is subject of this research. AOPs use metal oxides as semiconductors or organic dye as sensitizers with ultra violet or visible light to treat water sample [11]. The photocatalytic degradation of two commercial azo dyes Congo red (CR) and Benzopurpurine 4B (BP4B) in aqueous solution was investigated under UV-A light at different operating conditions, including irradiation time, $\mathrm{pH}$ solution, initial dye concentration, amount of catalyst, light intensity as well as band gap of other semiconductor groups by UV-spectrophotometric monitoring. The highest decomposition were obtained at $\mathrm{pH} 8$ as a result of 95.02 and $97.24 \%$ degradation efficiencies of CR and BP4B for 60 and $80 \mathrm{~min}$ of irradiation time respectively. Photodecomposition reactions of both dyes were correlated with

* Corresponding author 
pseudo-first-order kinetic model. For BP4B, the degradation data were satisfactory described by Langmuir-Hinshelwood (L-H) mechanism, whereas those of CR were not sufficient to conclude that the L-H mechanism is the most suitable one to describe the photo-catalytic process of CR. These findings can support the design of remediation processes and also assist in predict their fate in the environment [12].

\section{2- DETAILS EXPERIMENTAL}

\subsection{Material}

- Congo red C. R dye was supplied from ROTH, Germany.

- Zinc oxide supplied by BHD chemicals Ltd. Pool England.

- Distilled water.

Table (1) show Congo red properties

Table 1. Chemical and physical properties of Congo red.

\begin{tabular}{|l|l|}
\hline IUPAC.name. & $\begin{array}{l}\text { disodium 4-amino-3-[4-[4-(1-amino-4- } \\
\text { sulfonato-naphthalen-2- } \\
\text { yl)diazenylphenyl]phenyl]diazenyl- } \\
\text { naphthalene-1-sulfonate. }\end{array}$ \\
\hline Formula & $\mathrm{C}_{32} \mathrm{H}_{22} \mathrm{~N}_{6} \mathrm{Na}_{2} \mathrm{O}_{6} \mathrm{~S}_{2}$ \\
\hline $\begin{array}{l}\text { Molecular } \\
\text { weight }\end{array}$ & $696.66 . \mathrm{g} / \mathrm{mol}$. \\
\hline $\begin{array}{l}\text { Solubility in } \\
\text { water }\end{array}$ & $\begin{array}{l}\text { Soluble in water, yielding a red colloidal } \\
\text { solution } 1.16^{*} 10^{+5} \mathrm{mg} / 1 \text { at } 25^{\circ} \mathrm{C}\end{array}$ \\
\hline $\begin{array}{l}\text { Solubility in } \\
\text { ethanol }\end{array}$ & Soluble in ethanol \\
\hline $\begin{array}{l}\text { Solubility in } \\
\text { acetone }\end{array}$ & very slightly soluble \\
\hline $\begin{array}{l}\text { Solubility in } \\
\text { ether }\end{array}$ & Insoluble \\
\hline $\begin{array}{l}\text { Absorption } \\
\text { spectra }\end{array}$ & $497,347 \mathrm{~nm}$ \\
\hline pH & $8-9.5$ \\
\hline Odor & Odorless \\
\hline Melting point & $>360{ }^{\circ} \mathrm{C}$ \\
\hline Pka & 4.1 at $\left(25^{\circ} \mathrm{C}\right)$ \\
\hline
\end{tabular}

Congo red it is soluble in water, is a secondary di-azo dye, yielding a red colloidal solution.[13, 14].

However, Congo red it has a solid, clearly non covalent, liking to cellulose fibers'. Moreover, Congo red used in the cellulose industries. (cotton material, wood mash, and paper).has been relinquished, essentially in view of its. Poisonous quality and inclination.to run and change shading when contacted by sweat-soaked fingers $[15,16]$.

\subsection{Experimental Procedure}

The chemical compounds are Analytical grade and has been purchased from FLUKA. However, to determine the activation energy all experiment has been done in different temperatures. Moreover, to determine the effect of concentration on the process of photo degradation different concentrations have been used. In addition, the light source used in this research is LED light. Also water has been used in this research as solvent. The concentration change during photo degradation has been measured by spectrophotometer at $498 \mathrm{~nm}$ and $344 \mathrm{~nm}$. The reading was taken every 5 minutes.

\subsection{The photolytic systems}

Figure (1) illustrates the major part of photolytic system. However, the cell consists of double layer for circulation of water from and to thermostat. Moreover, to determine the absorption occurs during the time the ultraviolet-visible Spectrophotometer has been used which the type is PerkinElmer lambda 25.

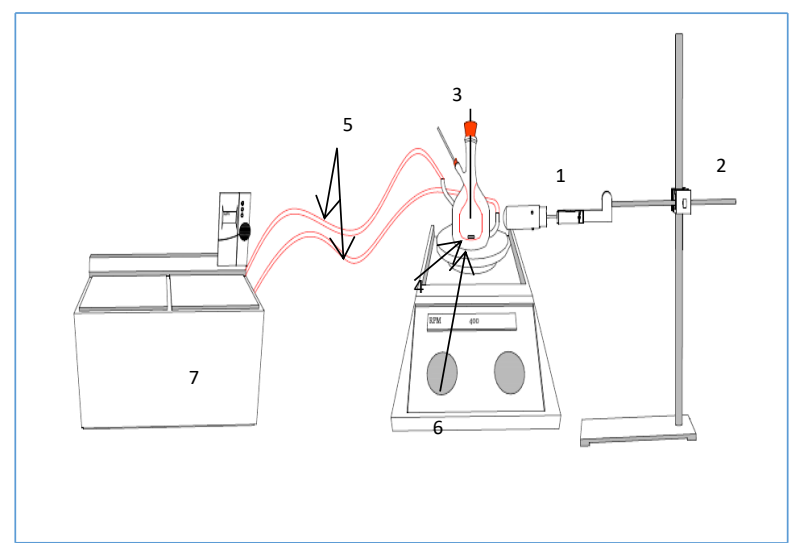

Figure 1. Diagram of photo-degradation system

1- Ultra violet (UV.) light has been used as light source.

2- Stand and clamp.

3- Photolytic cell is made from borosilicate which is transparent for ultraviolet and visible light.

4- Magnetic bar.

5- Inlet and outlet tube.

6- Magnetic stirrer.

\section{7- Thermostat.}

Mathematically; beer's law are used for the determination of intensity ratio according to the relation $(\mathrm{A}=\mathrm{abc})$ where $(\mathrm{A})$ is absorbance (a) is molar extinction coefficient, (b) is a path length and (c) is concentration [10] analysis by spectrophotometric kinetic method are differ from the equilibrium or stoichiometric methods, methods of kinetic are made under dynamic conditions in which the change in concentration of both reactant and product depend on the time.

\section{3- RESULTS AND DISCUSSION}

The concentration change during photo degradation has been measured by spectrophotometer at $498 \mathrm{~nm}$ and $344 \mathrm{~nm}$. The reading was taken every 5 minutes as in figure 2. Calibration curve have been drawn as in figure 3 .

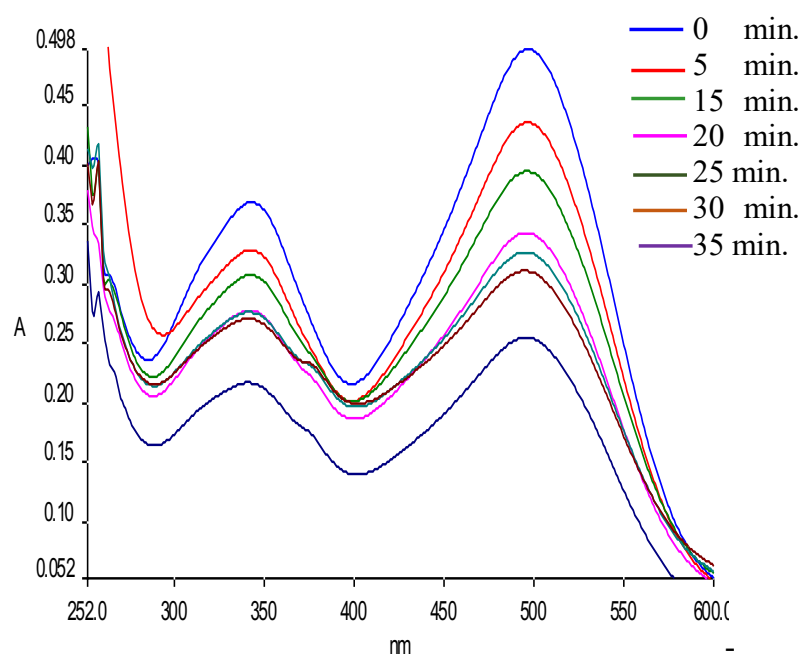

Figure 2. UV-Visible monitoring spectra of congo-red dye degradation $\left(0.4 \mathrm{~g} / \mathrm{L} \mathrm{ZnO}\right.$, TEMP. $20^{\circ} \mathrm{C}$, [C.R.] $\left.=10 \mathrm{mg} / \mathrm{L}\right)$ 


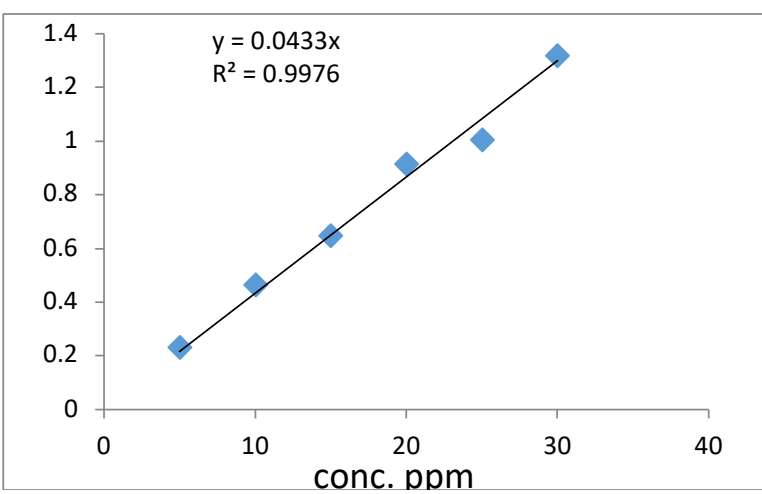

Figure 3. UV-Visible spectra calibration curve of congo-red dye in water as a solvent $498 \mathrm{~nm}$ at $20^{\circ} \mathrm{C}$.

Table 2. Molar absorptivity $(\varepsilon)$ and optical density (O.D)

\begin{tabular}{|l|l|l|}
\hline $\begin{array}{l}\text { Wave length }(\lambda) \\
(\mathrm{nm})\end{array}$ & O.D. & $\begin{array}{l}\varepsilon \\
\text { mol/L.cm }\end{array}$ \\
\hline 498 & 0.476 & 10639 \\
\hline
\end{tabular}

\subsection{Determination the order of degradation}

The rate of Congo-red degradation has been estimated by examining degradation of each peaks of $(498 \mathrm{~nm}, 344 \mathrm{~nm})$ it appears that the degradation of peak $498 \mathrm{~nm}$ is first order and $344 \mathrm{~nm}$ is pseudo zero order. Through plotting log-log graphical method and the theoretical approach have been used in order to determine the order of CR degradation as in the following equations [17-24].

Rate $=k[A]^{n}$

$\left(\text { Rate }=k[A]^{n}\right)_{1}$

$\overline{\left(\text { Rate }=k[A]^{n}\right)_{2}}$

$n=\frac{\log \text { Rate }_{1}-\log \text { Rate }_{2}}{\log [A]_{2}-\log [A]_{1}}$

Where $\mathrm{n}$ is the order of degradation

However; throughout all above procedure it has not gave an accurate result to make sure the order of degradation. Therefore another estimate has been done by plotting integral kinetic model (log concentration) as a function of time for examining zero, first and second orders kinetic as in figure 4 and 5. It appears that degradation of peak $498 \mathrm{~nm}$ is first order and $344 \mathrm{~nm}$ is pseudo zero order, the most fitted linear curve by measuring correlation coefficient determined the order of each peaks.

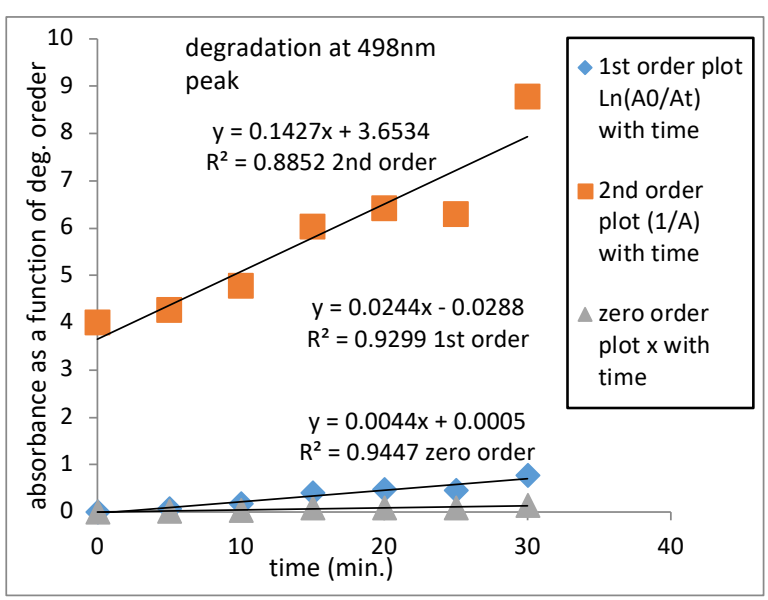

Figure 4. Zero, first and second integral kinetic model for determining the order of degradation at 498.

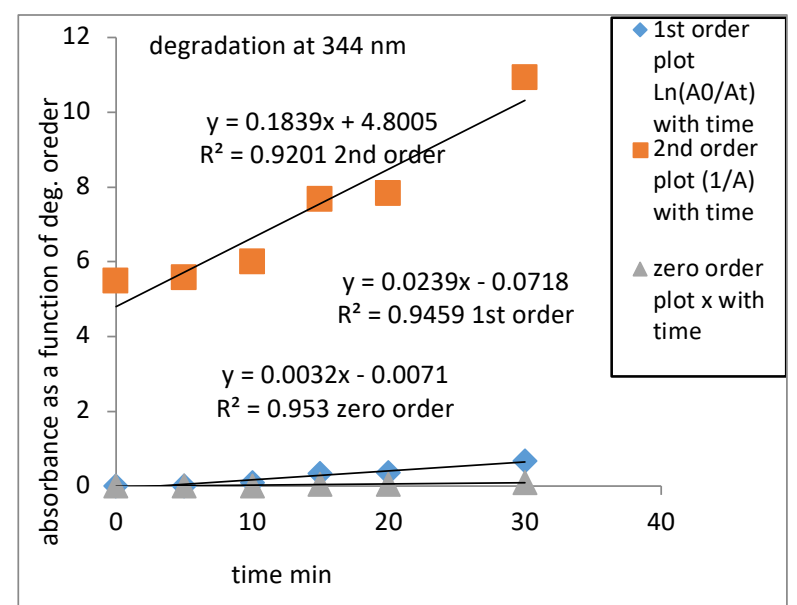

Figure 5. Zero first and second integral kinetic model for determining the order of degradation at $498 \mathrm{~nm}$.

\subsection{Effect of concentration}

The rate constant of degradation dose not remain constant by varying initial concentration. This may be due to secondary photo-chemical reactions that take place during photodegradation process and also this change perhaps due to quenching process, in which some intermediates absorb a Radiation and re-emit them as a form of heat do not undergo photolysis. Another striking point is that increase in concentration may change the order of degradation and therefore in some circumstances by increasing concentration the rate constant have been fluctuated as in table (3).

Table 3: The rate constant $\mathrm{k}$ of congo-red degradation at different concentrations.

\begin{tabular}{|l|l|l|l|l|l|l|}
\hline $\begin{array}{l}\text { Conc. } \\
\begin{array}{l}\text { Rate } \\
\text { constant } \\
\mathrm{k}\end{array}\end{array}$ & $\begin{array}{l}5 \mathrm{ppm} \\
\mathrm{ppm}\end{array}$ & $\begin{array}{l}15 \\
\mathrm{ppm}\end{array}$ & $\begin{array}{l}20 \\
\mathrm{ppm}\end{array}$ & $\begin{array}{l}25 \\
\mathrm{ppm}\end{array}$ & $\begin{array}{l}30 \\
\mathrm{ppm}\end{array}$ \\
\hline $\begin{array}{l}\text { K at } 498 \\
\text { (min-) }\end{array}$ & 0.0244 & 0.0159 & 0.0053 & 0.0095 & 0.01 & $\begin{array}{l}0.00 \\
68\end{array}$ \\
\hline $\begin{array}{l}\mathrm{K} \text { at } 344 \\
(\mathrm{M} / \mathrm{min})\end{array}$ & 0.0032 & 0.0043 & 0.0024 & 0.004 & & \\
\hline
\end{tabular}

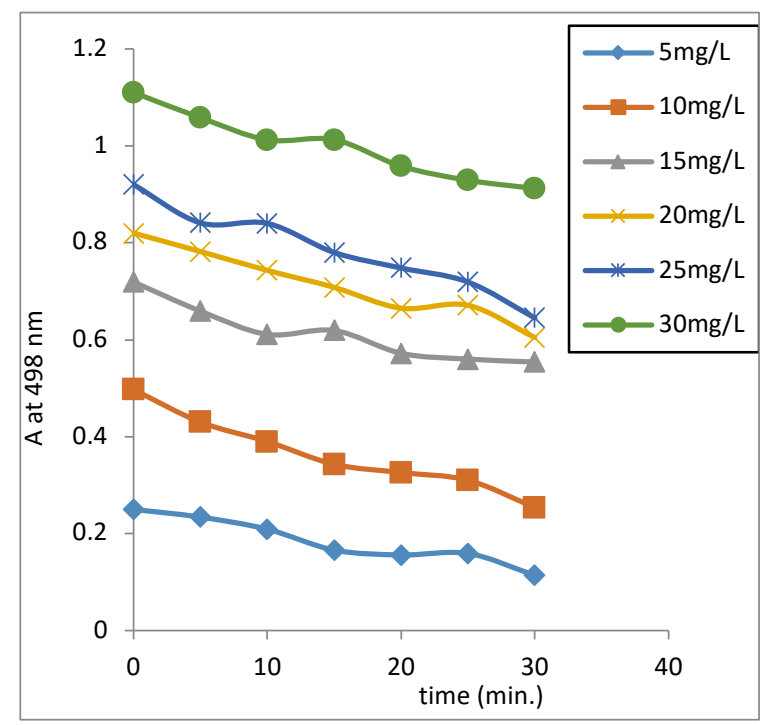

Figure 6. Absorbance as a function of temperature at different concentration $498 \mathrm{~nm}$ at $20^{\circ} \mathrm{C}$. 


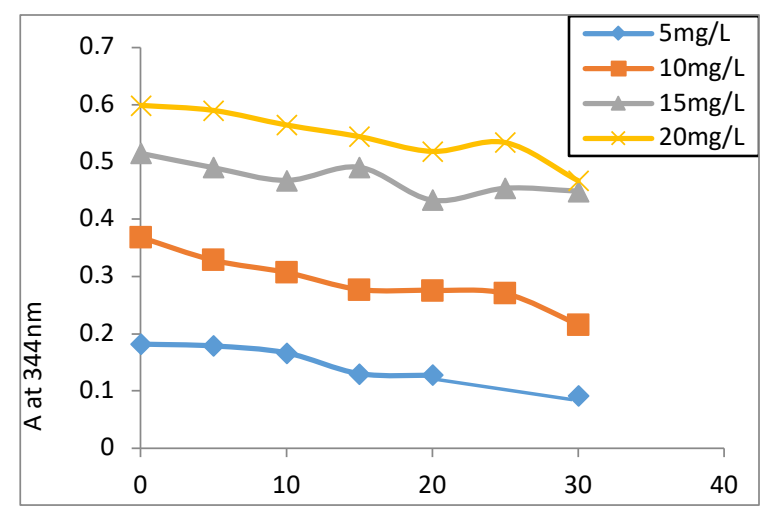

Figure 7. Absorbance as a function of temperature at different concentration $344 \mathrm{~nm} 20{ }^{\circ} \mathrm{C}$.

\subsection{Effect of temperature on degradation}

Arrhenius equation has been used to calculate the energy of activation [21]. time (min.)

$\mathrm{k}=\mathrm{Ae}^{-\mathrm{E}_{\mathrm{a}} / \mathrm{RT}}$

When $\mathrm{k}$ is rate constant, $\mathrm{A}$ is a frequency factor, $\mathrm{Ea}$ is activation energy, $\mathrm{T}$ is absolute temperature and $\mathrm{R}$ is universal gas constant $\left(8.314 * 10-3 \mathrm{KJ} \cdot \mathrm{mol}^{-1} \cdot \mathrm{K}^{-1}\right)$.

Overall, what stands out from table 4 is that the rate constants are increased with increasing temperature throughout the experiments. In spite of, increasing concentration, rate constant remain stable, in this experiment the rate constant is fluctuated. This may be due to the fact of quenching; during the degradation process new compounds are formed, which absorb the radiation causing less degradation. Another striking point is that increase in temperature may change the order of degradation and therefore in some circumstances by increasing temperature the rate constant have been decreased as in table (4) [14,17 and 22]. So that calculation of activation energy was failed as in figure (8).The activation was not measured because the kinetic order of degradation does not remain constant when temperature is changed. As it is obvious the product of degradation is multi product (many products) all molecules absorbed light which effect the kinetic of degradation. Moreover, due to multi product there is possibility of eximer and explics formation as a result the CR molecule may lose the gained energy from electromagnetic radiation as a form of heat and the process of degradation does not reach to completion. In addition, perhaps some molecules may take energy from $\mathrm{CR}$ die molecule in this case CR is acting as sensitizer and again the degradation is prevented, the temperature lead to increase the temperature lead the rate of all processes that have been just mentioned final, the measurement of kinetic parameters will not be accurate.

Table 4. The rate constant $\mathrm{k}$ of congo-red degradation at different temperature.

\begin{tabular}{|c|c|c|}
\hline temp. $\mathrm{k}$ & $\begin{array}{c}\text { rate const.k }\left(\mathrm{min}^{-}\right) \text {at } \\
498 \mathrm{~nm}\end{array}$ & $\begin{array}{c}\text { rate const.k }(\mathrm{M} / \mathrm{min} .) \text { at } \\
344 \mathrm{~nm}\end{array}$ \\
\hline 283 & 0.0235 & \\
\hline 298 & 0.0244 & 0.0032 \\
\hline 303 & 0.0264 & 0.0032 \\
\hline 308 & 0.0399 & 0.0033 \\
\hline 313 & 0.0224 & \\
\hline
\end{tabular}

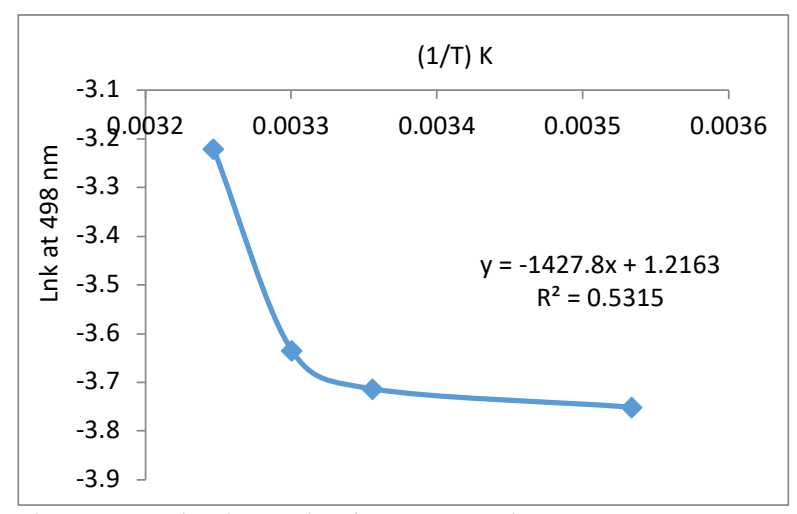

Figure 8. Arrhenius activation energy plot.

\subsection{Langmuir-Hinshelwood kinetic model (L-H)}

According to many researches, Langmuir-Hinshelwood rate equation model (L-H) has been successfully used for heterogeneous photo catalytic degradation to determine the relationship among initial degradation rate and initial concentration of the organic substrate [27]. LangmuirHinshelwood model system is given by

$\frac{1}{\mathrm{k}_{\mathrm{obs}}}=\frac{1}{\mathrm{k}_{\mathrm{c}} \mathrm{K}_{\mathrm{LH}}}+\frac{[\mathrm{MY}]_{0}}{\mathrm{k}_{\mathrm{c}}}$

Where $[\mathrm{MY}]_{0}$ is the initial concentration of organic compound $\left(\mathrm{mg} \mathrm{L}^{-1}\right) \mathrm{k}_{\mathrm{c}}$ is the rate constant of surface reaction $\left(\mathrm{mg} \mathrm{L}^{-1} \mathrm{~min}^{-1}\right)$, KHL Langmuir-Hinshelwood adsorption equilibrium constant (L $\left.\mathrm{mg}^{-1}\right)$ and kobs is the observed rate of degradation first order at $498 \mathrm{~nm}$. Many researches approximate (L-H) kinetic model to first order kinetics for the condition $\mathrm{KC} \ll 1$, while; it is approximated to zero order for the condition $K C \gg 1[28]$.

Langmuir-Hinshelwood rate equation model (L-H) is the most popular expression used to illustrate the degradation kinetics which occurs on the surface of semiconductors, this model explain the degradation occurring by semiconductors through the rate at which the organic molecules adsorb to the surface of semiconductor and degradation rate constant for such molecules as a result of oxidation reduction processes at a conduction and valance band [27-29].

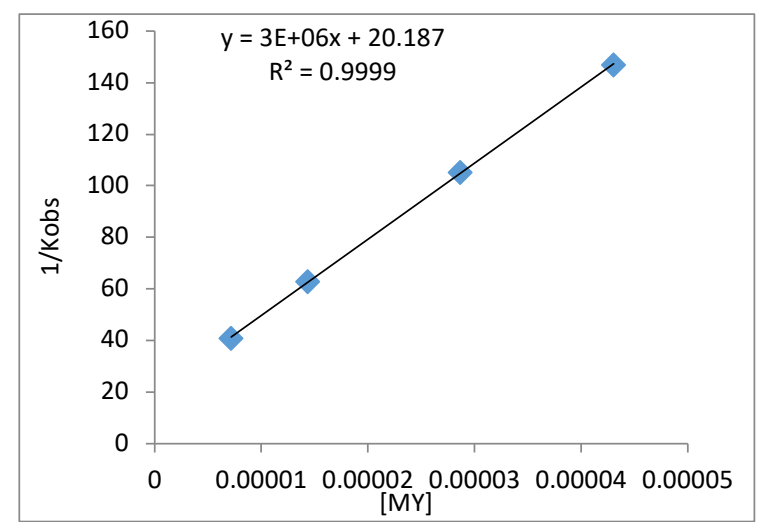

Figure 9. Linearized (L-H) model for measurement of $\mathrm{K}_{\mathrm{HL}}$ \& $\mathrm{kr}$ for degradation of CR.

\section{CONCLUSION}

All in all, the photo-degradation of this molecule is composed of primary photo excitation, and then it decomposes by thermal reaction which they are approximately first order at $498 \mathrm{~nm}$ and zero order at $344 \mathrm{~nm}$, that due to the fact this degradation is not pure straight line although it is not pure kinetic order.

The results show that the degradation of congo red dye were increased by increasing temperature from $20^{\circ} \mathrm{C}$ to $40{ }^{\circ} \mathrm{C}$ and then 
degreased at $50{ }^{\circ} \mathrm{C}$ this is maybe due to the desorption occur at the semiconductor surface while; in case of $10^{\circ} \mathrm{C}$ the rate constant was higher than $20^{\circ} \mathrm{C}$. This is maybe due to the increase adsorption between congo red molecule and surface of semiconductor.

\section{REFERENCES}

[1] National Library of Medicine.National Center for Biotechnology Information Available at: https://pubchem.ncbi.nlm.nih.gov/compound/Congo-red

[2] Laxma P V Reddy and Ki-Hyun Kim 2015 A review of photochemical approaches for the treatment of a wide range of pesticides J. Haz. Mate. pp. 325-35

[3] Karlaganis G, Marioni R, Sieber I and Weber A 2001 The elaboration of the 'Stockholm convention'on persistent organic pollutants (POPs): a negotiation process fraught with obstacles and opportunities Environmental Science pollution resources pp. 216-21.

[4] Rozman K K and Doull J 2000 Dose and time as variables of toxicity $J$. Toxic. 145 pp. $169-78$

[5] N. F. Gray Ph.D., S.D., 2010..Water Technology An Introduction for Environmental Scientists and Engineers.Third Edit., Dublin:.Butterworth-Heinemann is.an..imprint..of..Elsevier,.Said.Alahiane,.Samir...

Qourzal,.Mahmoud El.Ouardi,.Abdelhadi.Abaamrane, Ali.Assabbane. Factors.Influencing.the.Photocatalytic Degradation.of.Reactive.Yellow.145.by.TiO2-Coated NonWoven.Fibers..s.1. ‥American.Journal.of Analytical.Chemistry,.Vol..5(2014).445-454. http://dx.doi.org/10.4236/ajac.2014.58053......

[6] Galvez, J.B., 2003. Solar Detoxification, Almeria, Spain: United Nations Educational, Scientific and Cultural Organization.

[7] States, U.C. for E.R. information, 1998. \& EPA Handbook Advanced Photochemical Oxidation Processes.

[8] Donald N.Pavia, Gary M.Lampman, G.S.K., 2001. Introduction to Spectroscopy., p.366.

[9] Skoog, D.A., Holler, F.J. \& R.Crouch, S., 2007. Principles of Instrumental Analysis sexth edit., David Harris.

[10] James W. Robinson, Eileen M. Skelly Frame, G.M.F.I., 2005. UNDERGRADUATE INSTRUMENTAL ANALYSIS Sixth Edit., Marcel Dekker. Available at: http://www.dekker.com.

[11] Antonopoulou M, Evgenidou E, Lambropoulou D and Konstantinou I 2014 A review on advanced oxidation processes for the removal of taste and odor compounds from aqueous media, J. water res. pp. 215-34.

[12] Elaziouti , N. Laouedj and Bekka Ahmed. ZnO-Assisted Photocatalytic Degradation of Congo Red and Benzopurpurine $4 \mathrm{~B}$ in Aqueous Solution. Chemical Engineering \& Process Technology, 2011, vol. 2. Issue, 2.

[13] M. Movahedi, A.R. Mahjoub and S. Janitabar-Darzi. Photodegradation of Congo Red in Aqueous Solution on $\mathrm{ZnO}$ as an Alternative Catalyst to TiO2. J. Iran. Chem. Soc., Vol. 6, No. 3, (2009), 570-577.
[14] Venkatesh, S., Pandey, N.D. \& Quoff, A.R.. Decolorization of Synthetic Dye Solution Containing Congo Red By Advanced Oxidation Process ( AOP ). International Journal of Advanced Research in Civil,Structural,Environmental and Infrastructure Engineering and Developing,vol. 2(1), (2014).49-5

[15] Keshavarz, H. R. Pouretedal and M. H. Study of Congo red photodegradation kinetic catalyzed by $\mathrm{Zn} 1-\mathrm{XCuXS}$ and $\mathrm{Zn1-}$ XNiXS nanoparticles. 27, Shahin-shahr: International Journal of the Physical Sciences, 2011, Vol. 6. 10.5897/IJPS09.251.

[16] Shinwar A, Myasar KOptimization of Congo-red photo-catalytic degradation by Central Composite Design.J.IEEE.(2018),

[17] Robson MW. An Introduction to Chemical Kinetics. John Wiley \& Sons Ltd; 2004. Available at: www.wileyeurope.com or www.wiley.com.

[18] Santosh K. Upadhyay. Chemical Kinetics and Reaction Dynamics. New Delhi: Anamaya Publishers; 2006.

[19] Shinwar A. Idrees, S. A. Naman, Anees Shorachi photo-degradation of Trifluralin in aqeous suspension solution of acetonitril water. Msc. Thises 2015 UoZ.

[20] S. A. Naman, Lazgin A. Jamil FMJA-S. Photocatalytic Degradation Of Herbicide (Propanil) Using Semiconductor (TiO2, ZnO) In Aqueous Solution And Its Application In Local Water In Dohuk. 2006.

[21] Paula, Atkin's and Julio D 2006 physical chemistry (oxford : Oxford University Press)

[22] Sh A Idrees, S A Naman, A Shorachi; Kinetic and thermodynamic study of Trifluralin photodegradation by ultra violet light; 2018, doi:10.1088/1757-899X/454/1/012045

[23] Mohammed M. Molla-Babaker, Shinwar A. Idrees; Degradation of Congo Red Dye using Homogeneous Photo Fenton Catalyst Coupled with Oxygen Kinetics and Statistical Analysis, 2020; 6(1): 1-9; doi:10.9734/AJACR/2020/v6i130147.

[24] Haydar A., Shinwar A. Idrees, Sabir A., Reving A.; electrochemical degradation of alizarin black dye in aqueous medium using fe/al electrode, 2019; Vol. 7, No. 2, pp. 57-60; https://doi.org/10.25271/sjuoz.2019.7.2.601.

[25] Wardle and Brian 2009 Principles and Applications of Photochemistry. (Manchester, UK : A John Wiley \& Sons, Ltd., Publication)

[26] S Khezrianjoo HR. Langmuir-Hinshelwood Kinetic Expression for the Photocatalytic Degradation of Metanil Yellow Aqueous Solutions by ZnO Catalyst. Chem Sci J. 2012;85:1-8. Available at: $\mathrm{http}: / /$ astonjournals.com/csj

[27] Kumar, K Vasanth, K. Porkodi FR. Langmuir - Hinshelwood kinetics - A theoretical study. Catal Commun. 2008;9:82-84. doi:10.1016/j.catcom.2007.05.019

[28] Naman S A , Lazgin A Jamil and sheren othman I 2010 photocatalytic degradation and mineralization of paraquate, carbendazim, Acetamiprid as pesticides.Phd. desertation (zakho : university of zakho)

[29] Haydar A., Shinwar A., Reving A, Abraheem A., Sherwan M., Idrees S., Photo-catalytic degradation of Toluidine Blue Dye in aqueous medium Under Fluorescent Light.J.IEEE.(2018), 